\title{
Ecpleopus gaudichaudi Duméril and Bibron, 1839 (Squamata: Gymnophthalmidae) and Psychosaura agmosticha (Rodrigues, 2000) (Squamata: Scincidae): Distribution extension and new records from Atlantic Forest in Bahia
} state, Brazil

\author{
Eduardo José dos Reis Dias ${ }^{1^{*}}$ and Carlos Frederico Duarte Rocha ${ }^{2}$ \\ 1 Universidade Federal de Sergipe, Departamento de Biociências, Laboratório de Biologia e Ecologia de Vertebrados, Avenida Vereador Olímpio \\ Grande s/n, Centro. CEP 49500-000. Itabaiana, SE, Brazil. \\ 2 Universidade do Estado do Rio de Janeiro, Instituto de Biologia Roberto Alcântara Gomes, Departamento de Ecologia, Rua São Francisco Xavier \\ 524, Maracanã. CEP 20550-019. Rio de Janeiro, RJ, Brazil. \\ * Corresponding author, e-mail: ejrdias@hotmail.com
}

\begin{abstract}
We present the first record of Ecpleopus gaudichaudi and Psychosaura agmosticha for the state of Bahia, in the Atlantic Forest, Brazil. Ecpleopus gaudichaudi was found in the southernmost portion of the state, in the Restinga de Nova Viçosa, municipality of Nova Viçosa, whereas Psychosaura agmosticha was found in the northernmost portion of the state in the Restinga de Costa Azul, municipality of Jandaíra. This is the first time these lizard species were recorded in restinga habitats, and the first record of P. agmosticha in the Atlantic Forest domains.
\end{abstract}

Ecpleopus gaudichaudi Duméril and Bibron, 1839 is a small-bodied leaf-litter dwelling lizard endemic to the Brazilian Atlantic Forest recorded in the states of Minas Gerais, São Paulo, Rio de Janeiro, Espírito Santo, and Santa Catarina (Eisemberg et al. 2004; Dixo and Verdade 2006; Carvalho et al. 2007; Periri and Butti 2008; Costa et al. 2009; Tonini et al. 2010; Kunz et al. 2011; Ramos and Oliveira 2011), besides an isolated record from Goiás without precise locality data (Uzzell 1969).

Here we present three new records of Ecpleopus gaudichaudi from the state of Espírito Santo in Guarapari Municipality $\left(20^{\circ} 42^{\prime} \mathrm{S}, 40^{\circ} 30^{\prime} \mathrm{W}\right)$ housed at the reptile collection of Museu Paraense Emílio Goeldi (MPEG 25072 and 25073), Linhares Municipality (1941' S, 40 $06^{\prime}$ W) and Santa Tereza Municipality (19 ${ }^{\circ} 55^{\prime}$ S, 40 $40^{\circ}$ 'W) housed at the reptile collection of Museu de Zoologia da Universidade de São Paulo (MZUSP 3202 and 57251 respectively).

On 31 January 2005 we captured in pitfall traps three specimens of Ecpleopus gaudichaudi (24.8 - $31.0 \mathrm{~mm}$ snout vent length (SVL), $\bar{x}=27.02 \pm 1.89 \mathrm{~mm}$, Figure 1) at a restinga habitat in Nova Viçosa municipality $\left(17^{\circ} 58^{\prime} 26^{\prime \prime}\right.$ S, 39²8'29” W), Bahia state (Figure 2) (collection permit: 161/04 - IBAMA/RAN). This record extends the species known distribution $240 \mathrm{~km}$ northward from Linhares (the nearest locality record), state of Espírito Santo. It is the first record of the species in the state of Bahia and in the restinga ecosystem. Specimens were housed at the reptile collection of Museu de Zoologia da Universidade de São Paulo (MZUSP 98044-98046).

Psychosaura agmosticha Rodrigues, 2000 is a recently described skink species which has been recorded in the states of Rio Grande do Norte, Paraíba, Pernambuco,
Alagoas and Sergipe (Rodrigues 2000; Arzabe et al. 2005; Carvalho et al. 2005; Rodrigues and Santos 2008; Freire et al. 2009; Jorge and Freire 2010), northeastern Brazil. On 07 April 2004 we captured two specimens of $P$. agmosticha (64.1 and $62.2 \mathrm{~mm}$ SVL; Figure 3) during active search in the locality of Restinga de Costa Azul (11 40'28” S, $37^{\circ} 29^{\prime} 03^{\prime \prime}$ W), municipality of Jandaíra, Bahia state (Figure 4) (collection permit:056/02 - IBAMA/RAN). The new record extends the known geographical distribution of $P$. agmosticha ca. $250 \mathrm{~km}$ southward from the nearest locality record in the municipality of Xingó (09²4' S, 3758' W) state of Sergipe (Rodrigues 2000). All specimens were captured in the morning in thickets of thorny bromeliads in restinga habitat. The specimens were housed in the reptile collection of the Museu Nacional, Rio de Janeiro

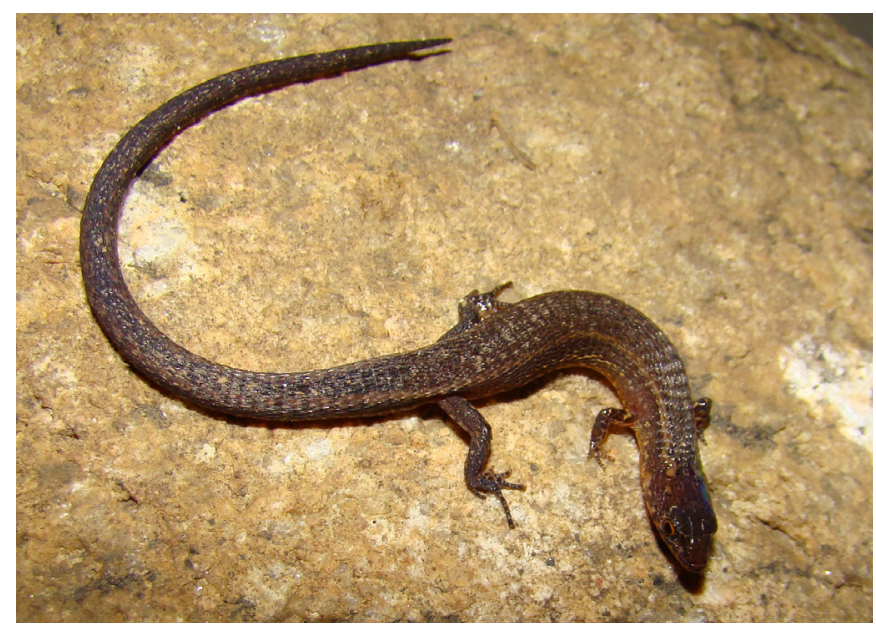

FigurE 1. Live adult of Ecpleopus gaudichaudi Duméril and Bibron, 1839 (Photo by Maurício Gomes). 
(MNRJ 16230 and 16231). Psychosaura agmosticha is a typical species of the semiarid Caatinga domain, usually occurring among dry cactuses, fallen logs, on the ground, and on thickets of the thorny bromeliad Bromelia laciniosa (Rodrigues 1987; 2000; Carvalho et al. 2005). This is the first time $P$. agmosticha was recorded in the restinga habitats as well as the first time in the Atlantic Forest. Other lizard species are known to occur both in the Caatinga and Atlantic Forest domains (Rodrigues 2003), and these founds add relevant information to understand biological connections between the semiarid Caatinga and the rainy Atlantic Forest.

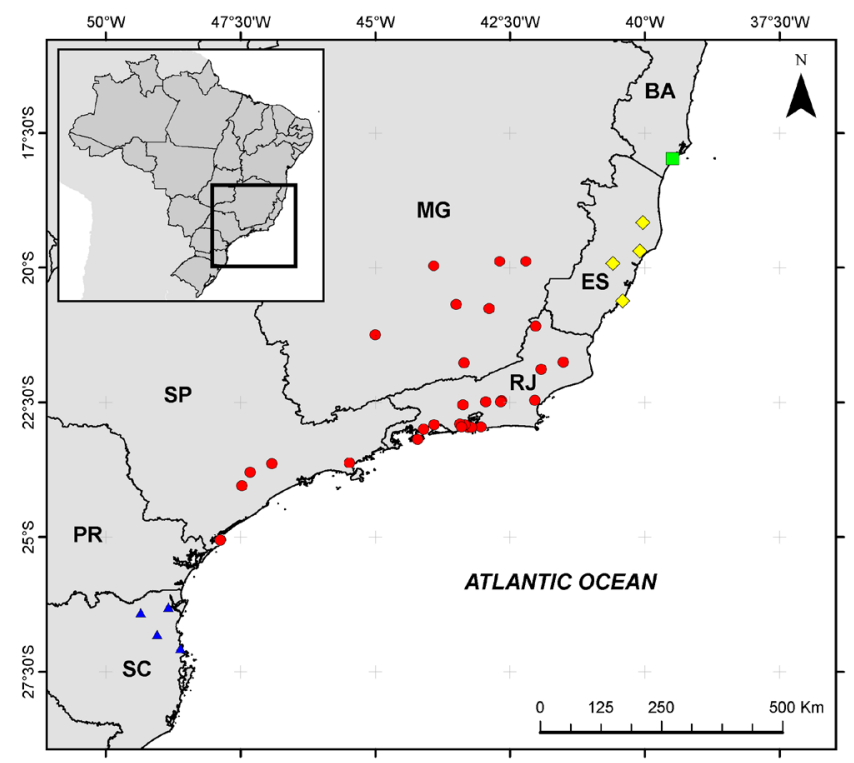

FIGURE 2. Known records of Ecpleopus gaudichaudi, Brazil. BA: Bahia; ES: Espírito Santo; RJ: Rio de Janeiro; MG: Minas Gerais; SP: São Paulo; PR: Paraná and SC: Santa Cataraina. Green square represents the new record, yellow rhombus represent reptile collections data and record in Tonini et al. 2010, red circles represent records in Ramos and Silveira 2011 and blue triangules records in Kunz et al. 2011.

In Jandaíra, Psychosaura agmosticha was found in syntopy with $P$. macrorhyncha, and associated to the bromeliads Aechmea multiflora and A. blanchetiana. The present record adds the fourth skink species occurring in Bahia, in addition to Brasiliscincus agilis, B. heathi and P. macrorhyncha (Vanzolini 1980; Rocha and Bergallo 1997; Rodrigues 2000).

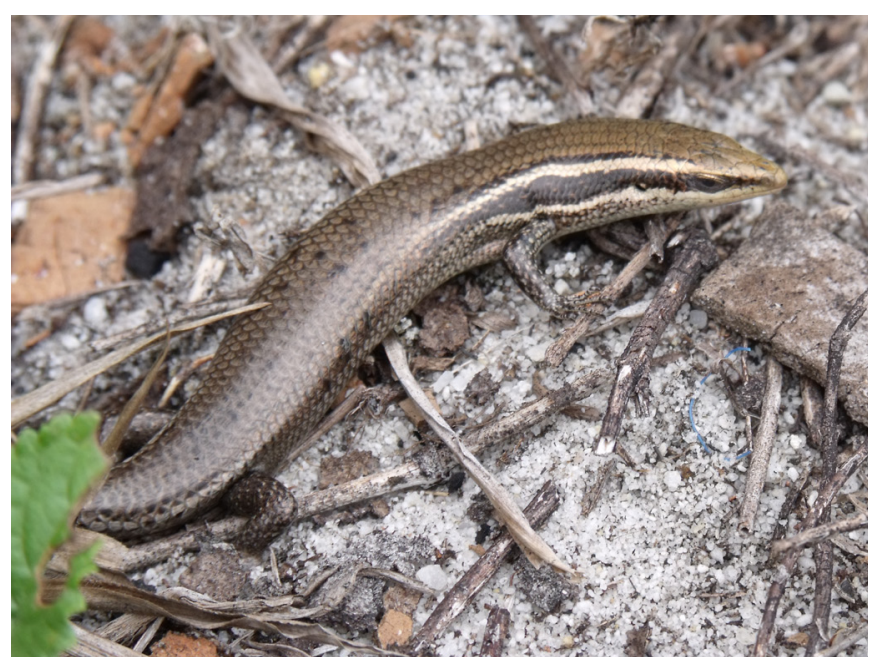

FIgURE 3. Live adult of Psychosaura agmosticha Rodrigues, 2000 (Photo by Eduardo Dias).

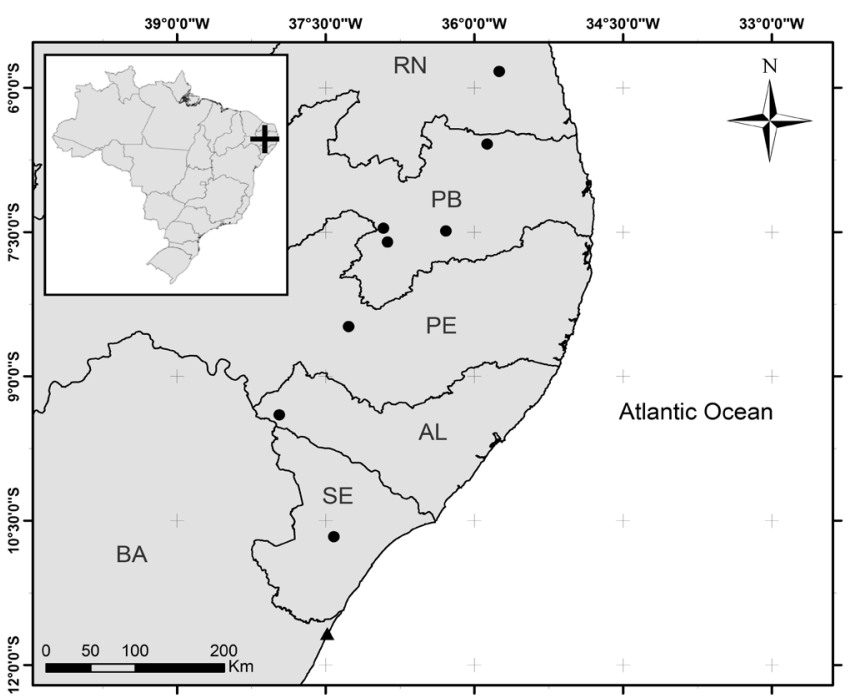

FIGURE 4. Known records of Psychosaura agmosticha, northeastern Brazil. BA: Bahia; SE: Sergipe; AL: Alagoas; PB: Paraíba; PE: Pernambuco; and RN: Rio Grande do Norte. Circles represent previously reported localities and triangle represents the new record, in Bahia.

ACKNOWLEDGMENTS: Thisstudy is a portion of the results of the "Programa de Ecologia, Conservação e Manejo de Ecossistemas do Sudeste Brasileiro" and of the Southeastern Brazilian Vertebrate Ecology Project (Vertebrate Ecology Laboratory), both of the Departamento de Ecologia, Instituto de Biologia, Universidade do Estado do Rio de Janeiro. We thank M. T. Rodrigues for confirming the identity of the two lizard species, Maurício Gomes for the photo of Ecpleopus gaudichaudi, João Luiz Gasparini for kindly providing personal informations. The referees Renato G. Faria, Henrique C. Costa, and Davi L. Pantoja for critically reviewing. Davor Vrcibradic and Jefferson Soares for revising the manuscript and offering helpful suggestions. Igor Rios do Rosário for drew the maps. The Instituto Brasileiro do Meio Ambiente e Recursos Naturais Renováveis - IBAMA conceded the collection permits. The Fundação de Amparo à Pesquisa do Estado do Rio de Janeiro (FAPERJ) provided a graduate fellowship for the first author (Process no. E-26/150.898/2001) and the Conselho Nacional do Desevolvimento Científico e Tecnológico (CNPq) provided research grants to the second author (processes 304791/20010-5 and 470265/2010-8). The Critical Ecosystem Partnership Fund (CEPF) and IDEAWILD for research grants for this study.

\section{LITERATURE CiTED}

Arzabe, C., G. Skuk, G. Santana, F.R. Delfim, Y.C.C. Lima and S.H.F. Abrantes. 2005. Herpetofauna da área do Curimataú, Paraíba; p. 264-280 In F.S. Ara'ujo, M.J.N. Rodal and M.R.V. Barbosa (ed.). Análise das variações da biodiversidade do Bioma Caatinga: suporte a estratégias regionais de conservação. Brasília: Ministério do Meio Ambiente.

Carvalho, C.M., J.C. Vilar and F.F. Oliveira. 2005. Répteis e Anfíbios; p. 39-61 In C.M. Carvalho and J.C. Vilar (ed.). Parque Nacional Serra de Itabaiana - Levantamento da Biota. Aracajú: IBAMA, Biologia Geral e Experimental - Universidade Federal de Sergipe.

Carvalho, A.L.G., A.F.B. Araújo and H.R. Silva. 2007. Lagartos da Marambaia, um remanescente insular de Restinga e Floresta Atlântica no Estado do Rio de Janeiro, Brasil. Biota Neotropica 7(2): 221-226.

Costa, H.C., V.D. Fernandes, A.C. Rodrigues and R.N. Feio. 2009. Lizards and Amphisbaenians, municipality of Viçosa, state of Minas Gerais, southeastern Brazil. Check List 5(3): 732-745.

Dixo, M and V.K. Verdade. 2006. Herpetofauna de serrapilheira da Reserva Florestal de Morro Grande, Cotia, SP. Biota Neotropica 6(2): 1-20.

Eisemberg, C.C, J. Cassimiro and J. Bertoluci. 2004. Notes on the diet of the rare gymnophthalmid lizard Ecpleopus gaudichaudii from southeastern Brazil. Herpetological Review 35(4): 336-337.

Freire, E.M.X., G. Skuk, M.F. Kolodiuk, L.B. Ribeiro, B.S. Maggi, L.S. Rodrigues, W.L.S. Vieira and A.C.G.P. Falcão. 2009. Répteis squamata das caatingas do seridó do Rio Grande do Norte e do cariri da Paraíba: síntese do conhecimento atual e perspectivas; p. 51-84 In E.M.X. Freire (ed.). Recursos naturais das caatingas: uma visão multidisciplinar. Natal: EDUFRN.

Jorge, J.S. and E.M.X. Freire. 2010. Geographic Distribution. Mabuya agmosticha (NCN). Herpetological Review 41(4): 512-513.

Kunz, T.S., I.R. Ghizoni-JR and M.E. Graipel. 2011. Reptilia, Squamata, Gymnophthalmidae, Ecpleopus gaudichaudi Duméril and Bibron, 1839: Distribution extension in the state of Santa Catarina, Brazil. Check List 7(1): 11-12. 
Perini, F.A. and M. Butti. 2008. Ecpleopus gaudichaudii (NCN). Reproduction. Herpetological Review 39(2): 222.

Ramos, L.O. and A.L. Silveira. 2011. New records and distribution map of Ecpleopus gaudichaudii (Reptilia, Squamata, Gymnophthalmidae) in southeastern Brazil. Herpetology Notes 4: 173-176.

Rocha, C.F.D. and H.G. Bergallo. 1997. Intercommunity variation in the distribution of abundance of lizard species in restinga habitats. Ciência e Cultura 49(4): 269-274.

Rodrigues, M.T. 1987. Sistemática, ecologia e zoogeografia dos Tropidurus do grupo torquatus ao sul do Rio Amazonas (Sauria, Iguanidae). Arquivos de Zoologia 31(3): 105-230.

Rodrigues, M.T. 2000. A new species of Mabuya (Squamata: Scincidae) from the semiarid Caatingas of northeastern Brazil. Papeis Avulsos de Zoologia 41(21): 313-328.

Rodrigues, M.T. 2003. Herpetofauna da Caatinga; p.181-236 In M. Tabarelli and J.M.C. Silva (ed.). Biodiversidade, ecologia e conservação da Caatinga. Recife: Universidade Federal de Pernambuco.
Rodrigues, M.T. and E.M. Santos. 2008. A new genus and species of eyelidless and limb reduced gymnophthalmid lizard from northeastern Brazil (Squamata, Gymnophthalmidae). Zootaxa 1873: 50-60.

Tonini, J.F.R., L.M. Carão, I.S. Pinto, J.L. Gasparini, Y.L.R. Leite and L.P. Costa. 2010. Non-volant tetrapods from Reserva Biológica de Duas Bocas,State of Espírito Santo, Southeastern Brazil. Biota Neotropica. 10(3): 339-351.

Uzzell, T. 1969. The status of the genera Ecpleopus, Arthroseps, and Aspidolaemus (Sauria, Teiidae). Postilla 135: 1-23.

Vanzolini, P.E., A.M. Ramos-Costa and L.J. Vitt. 1980. Répteis das caatingas. Rio de Janeiro: Academia Brasileira de Ciências. 161p.

RECEIVED: September 2011

ACCEPTED: June 2013

Published OnLINE: June 2013

EDITORIAL RESPONSIBILITY: Davi L. Pantoja 